\title{
FACTORING CONTRACT IN THE LIGHT OF DRAFTING THE MONTENEGRIN CIVIL CODE
}

\author{
Mijat Jocović * \\ Nikola Milović ${ }^{* *}$
}

\begin{abstract}
At the end of 2017, Montenegro undertook actions for drafting new civil codification. One of the dilemmas presented before the creators of the civil code is whether and to what extent autonomous agreements of business law are to be regulated. For the last two decades in Montenegro, there has been an increasing use of number of agreements in the economy which are regarded as autonomous creation of business practice. Due to its significance, the factoring contract is particularly important. Factoring contract does not have a long history of existence, nor legal regulation in the Montenegrin law. By 2017, factoring contract was an innominate contract of commercial law, which was subject to the general rules of the Law on Obligations and imperative norms of other legal areas. However, absence of legal regulation and presence of this contract in business practice have created the need to strengthen the legal certainty of all participants in this legal transaction, so it has been regulated by the provisions of a special law. The aim of this paper is to analyze factoring contract - the concept, essential elements and the content, and to provide answers to identified issues at stake, especially in the light of the work on the drafting the future Civil Code in Montenegro.
\end{abstract}

KEYWORDS: contract, factoring, civil code, Montenegro

\footnotetext{
* Assistant Professor at Faculty of Economics, University of Montenegro; mijatj@ucg.ac.me

**A Assistant Professor at Faculty of Economics, University of Montenegro; nmilovic@ucg.ac.me
} 


\section{INTRODUCTION}

At the very end of 2017, Montenegro undertook actions to create a new civil codification. In doing so, it has followed a number of post-socialist countries of Southeast Europe, which are returning to the tradition of civil codes. In a significant part of these countries, this trend of (re)codification of civil law has already been initiated or ended. ${ }^{1}$ Since codification has the principle of the overall regulation of relations in a particular matter, it raises the question of whether it should include those contracts created by the practice itself, and which are not regulated by law, or that have only recently been regulated by special laws. Thus, one of the challenges of codifying civil law is the question of whether and to what extent it is necessary to regulate certain contracts of business law, including factoring contract.

In the course of business operations, business entities face numerous challenges on the market - problems with liquidity and solvency, which result in bankruptcy proceedings, lack of financial resources, long and uncertain proceedings for collecting receivables, etc. The mentioned business practice at the global level has made room for new contracts of company law, among which factoring contract has a significant place. In order to highlight the concept and legal nature of this complex contract, which is one of the aims of this paper, it is necessary to understand that factoring is an economic activity that has its own different modalities. In general, factoring is the economic activity of financing companies by purchasing their receivables. On the other hand, factoring contract represents the form through which this economic activity is carried out. Because of the aforementioned, the subject and content of factoring contract define the specifics of performing this activity in each particular case. More specifically, the willingness of the contractual parties manifested in the concluded contract, determines the type of factoring in each particular case.

Regardless of the growing interest of the expert public in the legal aspects of factoring, for the time being, it's most important functions have not been suffi-

\footnotetext{
1 In Hungary, the recodification of civil law has been carried out, and the new Civil Code was adopted in 2013 and entered into force in 2014. In Poland, the work on the new codification of civil law began in 2002. In the Czech Republic, the new Civil Code was passed in 2012. In Romania, the new Civil Code was passed in 2011 (the work was started in 1989 and was completed in 2009). In the Russian Federation, the work on codification began in 1994 and lasted until 2006 (the fourth part came into force in 2008). The Civil Code of Lithuania entered into force on 1 July 2001. In 2006, the Government of the Republic of Serbia established the Commission for drafting of the Civil Code. At the end of 2010, the Government of the Republic of Macedonia established the Commission for the drafting of the Civil Code of the Republic of Macedonia. In March 2015, the Kosovo Ministry of Justice appointed the Commission for the drafting of the Civil Code.
} 
ciently clarified as the assumption is that factoring is above all the method for collecting receivables. This is particularly evident in underdeveloped economies and legal systems that have no long tradition of existence, nor regulation of this contract. In comparative business practice, in addition to collecting receivables, other functions are carried out through factoring, such as the crediting function of factoring; bookkeeping (outsourcing function of factoring); insurance and collection of receivables (the risk of collectability is assumed by the factor). ${ }^{2}$ Also, in comparative business practice, the factor performs other tasks on the client's behalf - testing the debtor's creditworthiness, tax calculation, statistical records, etc. Due to these functions, factoring is traditionally considered useful for small and medium size-enterprises which do not have their own, sufficiently developed accounting, marketing, and legal services, and have the need for these services. ${ }^{3}$ Regardless of the fact that the main users of factoring services are small and medium size enterprises, factoring is used in the public and private sector, among domestic and export-oriented enterprises, in different areas of the economy - industry, services, agriculture, etc. ${ }^{4}$

Therefore, depending on the way you look at it, factoring has its accounting, economic-financial, as well as legal aspects. In addition to the characteristics of obligation and legal nature, factoring has its status characteristics - such as the form and conditions for the establishment of factoring companies, obtaining a work permit, control of operation of factoring companies, etc. From the point of view of legal science, factoring contract leaves room for many different interpretations due to its complexity. First, is it necessary to regulate it - nominate or innominate contract? Second, to what extent is factoring to be regulated - does the over-regulation also mean limitation of the creation of new forms of this legal transaction? Third, does the regulation mean accepting or taking the text from the adopted international conventions, or does it need to be adapted to the needs of the economy in which the business of factoring companies is performed? Fourth, should factoring, as well as other innominate economic agreements, be regulated by special laws (as it is the case in the law of Montenegro) or within the existing Law on Obligations, through its amendments, or through the provisions of the Civil Code? The aim of this paper is to analyze factoring contract - the concept, essential elements and the content,

\footnotetext{
2 See: Milenković-Kerković, T.; Atanasković, Ž.: Ugovor o faktoringu u Srbiji-Zbog čega je potrebno regulisati faktoring?, 7(9)2013, Pravo i privreda - časopis za privrednopravnu teoriju i praksu, p. 197-215.

3 Radomir, Đ. Međunarodno privredno pravo, Beograd, 2004, p. 505-515.

4 Milenkovic-Kerković, T.; Dencic-Mihajlov, K.: Factoring in the Changing Environment: Legal and Financial Aspects, 44 (1) 2012, Procedia - Social and Behavioral Sciences, p. 428 435 .
} 
and to provide answers to these questions after the analysis, especially in the light of the work on the drafting of the future Civil Code in Montenegro.

\section{THE IMPORTANCE, HISTORY AND THE LEGAL NATURE OF FACTORING OPERATIONS}

Due to its various functions, factoring has experienced expansion throughout the world in the last decades. ${ }^{5}$ Specifically, faced with financial problems, by means of factoring, primarily small and medium-size enterprises solve the liquidity problem through provision of funds in less time than the maturity of receivables. ${ }^{6}$ On the other hand, the interest of the factoring company is reflected in the commission fee (1-3\%) for the purchase of receivables and interest for funds paid before collection of receivables. ${ }^{7}$ It should be emphasized that factoring does not increase liabilities of the company, because financing is based on assets. Additionally, factoring is becoming a significant instrument for financing exports in international trade. ${ }^{8}$ In economic theory, it is emphasized that due to these functions, factoring contributes to the increase of competitiveness of business entities, increase of competition in the financial market, or decrease in the price of capital. ${ }^{9}$ On the other hand, as negative aspects (risks) of factoring, are high costs for the client, as well as the risk of insolvency when collecting the receivables for the factor. ${ }^{10}$

Although factoring contract has not been legally regulated for years, this legal transaction has a relatively long history of existence. Due to its foundations in mediation, representation, or commission, legal theory states various historical data on the occurrence of this contract - from the time of the Hammurabi Law,

\footnotetext{
5 According to FCI - Factors Chain International, the world's total turnover of factoring reached $\$ 760$ billion in 2003, which is an increase of $67 \%$ compared to 1988 . In 2015, the factoring turnover was impressive $€ 2,373$ billion. Factors Chain International, Annual Review 2016, p. 2.

6 Bakker, M. et al.: Financing Small and Medium-size Enterprises with Factoring: Global Growth

and Its Potential in Eastern Europe, The World Bank, 2004. (Accessed at http://documents. worldbank.org/curated/en/293341468770661333/pdf/wps3342.pdf).

7 Mikerević, D.: Šanse i zamke faktoringa u saniranju nelikvidnosti preduzeća i privrede, 9(18) 2013, Acta Economica, 191-217.

8 Vukadinović, R.: Značaj i uloga faktoringa kao instrumenta finansiranja izvoza - iskustva novih članica Evropske unije, 165(1) 2005, Economic Annals, p. 81-104.

9 Ristić, D.; Rička, Ž.: Mogućnost korišćenja faktoringa na tržištu Bosne i Hercegovine i regije, 17(35) 2015, Tranzicija, p. 57-75.

10 Spasić, I. et al:: Factoring - instrument of financing in business practice - some important legal aspects, 25(1) 2012 Ekonomska istraživanja, p. 191-211.
} 
through colonial conquests in the Middle Ages, when European manufacturers and traders used the services of factors (agents) from overseas countries, to place goods and collect the purchase price with their help. However, in theory, today's form of factoring operation is the closest to the emergence of business practice from the XIX century in the United States when the import of textiles was prohibited or restricted by the customs tariff. In this situation, the original agents lost the opportunity to earn on the import of goods, and gradually began to finance and grant loans to domestic producers of textiles, in order to enable the continued sale of textile goods. In this situation, the manufacturers demanded from the agents a payment guarantee through advances. ${ }^{11}$ Over time, this feature expanded, so instead of giving advances, factors began to purchase receivables of their clients (credit function). These advantages of factoring operations in the 1960s contributed to its expansion process in Europe. In the end, this economic activity took off even in European transition countries, primarily through branches founded by parent banks and other financial institutions operating within them.

In Montenegro, factoring operation relates to the period of the financial crisis since 2008. Namely, factoring was used as a means by which banks in Montenegro were released from loans that burdened their balance sheets because they were not collectible. By means of factoring, banks transferred such loans to factoring companies that were usually established by parent banks. According to the data of the Central Bank of Montenegro, in the period between 2006 and 2016 banks sold assets worth nearly 846.9 million euros..$^{12}$ This way, the debt of the economy towards the banks was nominally reduced, while the debts formally remained in the accounts of the debtor - economy (only the creditor was changed). Today, in Montenegro factoring operations are performed on a limited scale. Therefore, for the time being, the economy did not recognize the stated advantages of this legal transaction. Additionally, one period of the non-existence of the relevant legislation was an obstacle to the development of factoring services. On the other hand, the insolvency of the economy creates the need for the development of factoring, and in the future period activities in this sector are expected to grow. ${ }^{13}$ Following the practice primarily from the

\footnotetext{
11 Milenković-Kerković, T.; Atanasković, Ž:: Ugovor o faktoringu u Srbiji - Zbog čega je potrebno regulisati faktoring?, 7(9) 2013, Pravo i privreda - časopis za privrednopravnu teoriju i praksu, p. 197-215.

12 Central Bank of Montenegro, Report on the stability of the financial system for 2017, p. 21. (accessed at: https://www.cbcg.me/slike_i_fajlovi/eng/fajlovi/fajlovi_publikacije/fin_stabilnost/financial_stability_report__2017.pdf).

13 According to the data of the Central Bank of Montenegro, during 2016, the blocked amount on the basis of the debt of judgment debtors in the process of enforced collection increased to $€ 628.3$ million, or $16.7 \%$ of GDP (compared to $15.1 \%$ of GDP in the end 2015 , or $3 \%$ of
} 
countries in the region, Montenegro has regulated the most important issues relevant to the factoring, by adopting the Law on Financial Leasing, Factoring, Purchase of Receivables, Micro-Lending and Credit-Guarantee Operations (hereinafter: Law on Provision of Financial Services), as well as issues related to the regulation of factoring contract. In this paper, certain provisions of this Law will be analyzed in detail, with the aim to identify whether there is any room for further improvement. ${ }^{14}$

\section{THE CONCEPT, ENTITIES AND CHARACTERISTICS OF THE FACTORING CONTRACT}

For many years, factoring contract has been considered a product of autonomous commercial law in most countries of continental legal traditions. In the last decades, there has been an apparent trend in its legal regulation. Internationally, the most important source of law is the Convention on International Factoring adopted by the International Institute for the Unification of Private Law - UNIDROIT in 1988 at the International Diplomatic Conference in Ottawa. Many countries, including Montenegro, have legally regulated factoring, by implementing basic provisions of this Convention into their national legislation. Additionally, adjustment to national laws was necessary also because of the fact that the Convention regulates exclusively international factoring. In the preamble to the Convention, the contracting parties point out that they are aware of the fact that international factoring will play a significant role in the development of international trade and, consequently, accept the importance of adopting uniform rules for the creation of a legal framework that will facilitate international factoring while ensuring fair balance between the parties involved in legal transaction of factoring. The Convention contains 23 articles grouped into four chapters. In addition to the Convention, the UNCITRAL - Convention on the Assignment of Receivables in International Trade from 2001 is also used as an international source of Law on Factoring.

In legal theory and legislation there are different definitions of this legal transaction. Due to the complexity of the factoring transaction, it is very demanding to include all elements of the factoring contract in one definition. For example, professor Vasiljević defines factoring contract as a legal transaction where the factor purchases the client's receivables at a discount (on maturity or before maturity), with or without the right to recourse the factor towards the seller

GDP at the end of 2007). Central Bank of Montenegro, Report on the stability of the financial system for 2017, p. 9-10.

14 Law on Financial Leasing, Factoring, Purchase of Receivables, Micro-Lending and Credit-Guarantee Operations (Official Gazzette of Montenego, no. 073/17). 
of receivables (true factoring). That is, a legal transaction where the assignee undertakes to transfer existing or future receivables for the collection to the factor, and with the commission and charging the costs, the factor undertakes to collect the receivables and possibly guarantee payment to the client (unreal factoring). ${ }^{15}$ In the legal theory, factoring is assumed to be a contract where one party - factor undertakes to take over (undue, short-term) receivables of the other party - the client, collect them, acting on his own behalf and for his own account, and to pay the client the counter value of the receivables immediately or at a predetermined time and guarantee payment under certain conditions, while the client undertakes to pay the appropriate fee for this to the factor. ${ }^{16}$ Under factoring contract, the legal sale of receivables that the business entity has towards the debtor is made to the bank, where the bank takes over the collection of the receivables. ${ }^{17}$

Unlike legal theory, the legislation of countries in the region has a significantly narrower definition of factoring contract (the definitions will be given below). Convention on International Factoring defines the factoring contract as a contract whereby the client transfers to the factor the receivables from the concluded basic sale agreement with the debtor, where the factor performs at least two of the following functions:

1. Financing the client, including loans and advance payments;

2. Keeping accounts related to receivables;

3. Collection of receivables,

4. Provision against the risk of non-payment of receivables. ${ }^{18}$

Therefore, the definition of a factoring contract should be considered depending on the functions taken over by the factor, as well as the specific types of factoring contract. From the above definitions it can be concluded that factoring contract is a complex legal transaction which contains the elements of several different agreements. Nevertheless, this is a sui generis agreement, which is confirmed by its increasing legal regulation in comparative law. In the law of Montenegro, factoring contract is nominate, onerous, bilateral (synallagmatic) contract, formal and mixed contract. Furthermore, it is a standard form contract, due to the frequency of conclusions of contracts and practices created by

\footnotetext{
15 Vasiljević, M.: Trgovinsko pravo, Beograd, 2011, p. 370.

16 Brkić, A.: Normativno uređenje ugovora o faktoringu u svijetlu domaćih i međunarodnih izvora prava, 9(1) 2010, Anali Pravnog fakulteta Univerziteta u Zenici, p. 177-200.

17 Milosavljević, M.: Privredno ugovorno pravo, Novi Sad, 2009, p. 121.

18 UNIDROIT Convention on international factoring, Art 1. (accessed at: https://www.unidroit.org/instruments/factoring).
} 
factoring companies. Participants in a factoring operation are creditor, debtor, and factor. The creditor and debtor is a legal or natural person claiming or owing the object of factoring based on the underlying activity. The factor is a business organization purchasing the object of factoring pursuant to the factoring contract. ${ }^{19}$ Factors are usually banking institutions or specialized institutions that usually deal with this activity as primary or secondary activity. On the other hand, clients which conclude a factoring contract are mainly small and medium-size enterprises.

\section{FACTORING CONTRACT IN THE LAW OF MONTENEGRO}

Factoring contract does not have a long history of existence, nor legal regulation in the law of Montenegro. Until the adoption of the Law on Provision of Financial Services, factoring contract was an innominate contract of commercial law, which was subject to the general rules of the Law on Obligations and imperative norms from other legal areas. However, the absence of the legal regulation and the presence of this contract in business practice have created the need to strengthen the legal certainty of all participants in this legal transaction; first of all, the insufficient number of informed clients. At the same time, the absence of legal regulation has also had negative effects on factoring service providers, as the absence of conditions for performing these transactions reduced confidence in their operation. By regulating factoring, i.e. factoring service providers, primarily through the regulation of the minimum basic capital, a selection of potential factoring service providers has been made and the possibility of establishing ad hoc factoring service providers has been eliminated. However, the question arising is what the legislator has achieved through provisions that define the factoring contract? The Law on Provision of Financial Services, in addition to factoring, includes the activities of financial leasing, purchase of receivables, micro-crediting and credit-guarantee operations. In addition to the obligation law issues, the Law also regulates the establishment, operation, and control of the business of companies that are engaged in these activities.

\subsection{FACTORING TRANSACTION AND FACTORING CONTRACT}

Following the approach of countries in the region mostly, the legislator in Montenegro has made a distinction between factoring transactions and factoring contracts. Nevertheless, we consider that this approach is not fully com-

19 Law on Provision of Financial Services, Art. 56. 
plete and precise in a linguistic and formal-legal manner. Namely, Article 55, paragraph 1 of this Law defines factoring operations as follows:

"Factoring is a legal transaction where a person who carries out factoring operations (factor) purchases the object of factoring resulting from a legal transaction of sale of goods or delivery of services concluded between the creditor of the object of factoring and the debtor of the object of factoring (hereinafter: the underlying activity)."

Article 63, paragraph 1 provides the following definition of the factoring contract:

"The factoring contract shall be a contract concluded in writing under which the factor undertakes to provide factoring service and the creditor of the underlying activity to transfer the object of factoring to the factor, as well as that the factor shall pay a relevant fee, depending on the contracted type of factoring."

From the above definitions of the concept of factoring operations and factoring contract, it can, it remains unclear why the legislator decided to define them separately. It is particularly necessary that the norms in this part be clear, because of the need that these concepts be understood in the business community. We believe that it was not necessary that the concept of a factoring be legally defined (or not in this way) but only regulate its essential elements and form. Especially for the reason that it is impossible to include different and very complex forms of factoring which are separately regulated with a single definition. Analyzing the above definitions, arises the question what is the subject of the factoring contract? According to the Law, in the part where the factoring operation is regulated, it is stipulated that the object of factoring shall be any existing or future, total or partial, due or undue, short-term monetary receivable generated as a result of the underlying activity. Hence, the subject of the factoring contract is the subject of factoring transaction?! The aforementioned norms have not been linguistically or logically fully agreed upon. Furthermore, in the definition of a factoring contract, it is stated that: under factoring contract, the factor undertakes to provide factoring service. The question arises - what is the factoring service, because it is not defined by the provisions of the law. Terminological inappropriateness is apparent further in the text of the Law, when part of the provisions regulating the factoring contract discuss about types of factoring and similar. Therefore, it was necessary to define the concept of factoring and factoring contract more precisely. Analyzing the provisions of the laws of the countries from the region, it can be concluded that this concept has been taken over from Croatian law, but not entirely. ${ }^{20}$ Namely, the law of Croatia defines factoring as a legal transaction where a provider of factoring

20 Law on Factoring, (NN, 94/14, 85/15, 41/16). 
service, purchases factoring object with or without the right to recourse (Article 4), pursuant to and in accordance with the factoring contract concluded with the supplier and/or buyer. After defining factoring, the Law regulates the types of factoring (not types of the factoring contract!), and then the concept, essential elements of the factoring contract. The law defines the factoring contract as follows: Under the factoring contract, provider of factoring undertakes to provide a factoring service to the supplier with the right to charge interest, factoring fees, administrative fees and other factoring costs established by the contract. $^{21}$ On the other hand, the law in Serbia does not define the factoring contract, but its essential elements. ${ }^{22}$ Also, the concept of factoring is defined more simply in the Serbian law. The Factoring Law in Serbia stipulates that factoring is a financial service of selling and purchasing existing non-matured or future short-term receivable arising from agreements on the sale of goods or provision of services either nationally or abroad. ${ }^{23}$

\subsection{TYPES OF FACTORING}

The development of factoring as an economic activity has led to the creation of various modalities of this legal transaction. First, the territorial principle distinguishes between domestic and international factoring. International factoring is a type of factoring where the object of factoring is derived from the underlying activity with a non-resident. International factoring is carried out in a single-factor system (one factor participates) and two-factor system (at least two factors participate, one of which is a foreign factor).$^{24}$ If the subject of the obligation is a criterion, we distinguish between true factoring and quasi factoring. In a situation where the factor assumes the lending functions and del credere function, it is true or complete factoring. For quasi factoring (not true factoring), the factor takes over receivables only for the purpose of collection, and as a rule, does not guarantee the collection of receivables. ${ }^{25}$

The Law on Provision of Financial Services regulates the so-called reverse factoring. This is a type of factoring where the factor and the debtor of the object of factoring contract a program to pay the object of reverse factoring to the creditor of the object reverse factoring in such manner as that the factor

\footnotetext{
21 Croatian law on Factoring, Art. 13.

22 Factoring Law, (Official Gazzette of the Republic of Serbia no. 62/2013, 30/2018), art. 19 and 20 .

23 Factoring Law of Serbia, Art. 2 para. 1 item 1.

24 Law on Provision of Financial Services, Art. 61.

25 Vasiljević, M.: Trgovinsko pravo, Beograd, p. 371.
} 
undertakes to pay the object of reverse factoring before its due or upon the object of reverse factoring becomes due upon request of the creditor of the object of reverse factoring or upon instructions of the debtor of the object of reverse factoring, with transfer of so paid object of reverse factoring from the creditor of the object of reverse factoring to the factor. Regardless of the fact that we consider that the mentioned definition could have been more precise, the essence of reverse factoring is generally the interest of a major buyer to enable its suppliers to finance their receivables more easily, at an interest rate lower than the one they would regularly receive. ${ }^{26}$ Additionally, the reverse factoring is based on debt collection, while true factoring is based upon a cession. ${ }^{27}$

\subsection{ELEMENTS OF THE FACTORING CONTRACT}

Law on Provision of Financial Services regulates important elements of the factoring contract. Namely, Article 64 of the Law stipulates that the factoring contract shall in particular contain the following elements:

- identification data on contractual parties;

- data on type of factoring;

- data on underlying activity or object of factoring resulting from such activity;

- data on amount, the manner of calculation and payment of value of the object of factoring;

- data on amount, the manner of calculation and payment of the factoring fee, interests, payment and refund of the advance payments,

- the administrative fees and other fees, depending on the type of factoring;

- the term of the factoring contract;

- date the factoring contract is concluded; and

- signatures of the contractual parties.

However, the Law does not contain a provision as to whether a factoring contract is null and void when it does not contain the listed elements. When it comes to the nullity of the factoring contract, the Law provides that the factoring contract having as its subject the sale of the object of factoring which was the subject of an earlier factoring contract shall be null and void.

26 Marković, V.: Ugovor o faktoringu u pravu Republike Srbije, 5(2) 2014, Pravni zapisi, p. 493-504.

27 Matić, B.: Obrnuti faktoring u domaćem zakonodavstvu, 1(3) 2014, Pravo i privreda, p. $268-285$. 


\subsection{RIGHTS, OBLIGATIONS AND LIABILITIES OF CONTRACTUAL PARTIES}

The law does not regulate the rights and obligations of contractual parties, but the obligations of the participants in the factoring transaction (!). In accordance with the Law, the creditor is obliged to deliver the following to the factor when transferring the object of factoring: 1) original or certified copy of the contract on underlying transaction, or a contract upon which the object of factoring was formed and/or original or certified copy of the invoice or other documents proving the basis for and identifying the object of factoring, and proof of notification of the debtor on the sale of the object of factoring, if there is a notification obligation of the debtor, except in cases when it is contracted for the creditor to proceed with collection of the full amount of the object of factoring on his behalf and for the account of the factor. Upon submission of a notice on the sale of the object of factoring, the debtor is obliged to pay for the object of factoring to the factor. Also, in case of paying for the object of factoring to the creditor, the debtor shall is not relieved of the obligation to the factor if notified of the sale of the object of factoring before the payment, (Article 69). In addition to the general rules of Law on Obligations, the Law provides that the creditor is liable to the factor for existence, reasonableness and accuracy of the value of the object of factoring. Also, creditor guarantees to the factor that the object of factoring is free of pledge and other encumbrances, as well as objections and other rights of third parties, unless otherwise stipulated in the factoring contract. Therefore, in this case, the contract can exclude the liability of the creditor. In the event that the factoring contract does not exclude the liability of the creditor, the factor has the right of recourse against the creditor even when the non-recourse factoring is contracted.

The legislator did not regulate the time of termination of the factoring contract. For example, the law in Serbia stipulates that the factoring agreement shall cease to have effect upon the expiry of its original term, and if no term is stipulated, an agreement may not cease to have effect before the collection of all receivables assigned or the exercise of recourse by the factor (Article 21).

\section{COMPARATIVE LEGAL APPROACH TO REGULATION OF FACTORING}

Comparative law in the last decades, talks about a change in relation to the regulation of factoring. Namely, in a significant number of countries in Europe factoring contract is regulated by special laws or within the laws regulating 
the obligation relations, that is, the civil-legal relations. ${ }^{28}$ This trend from comparative law is particularly present in the countries from the region. Namely, almost all countries from the region regulate the factoring contract with special laws. For example, there is a special law regulating factoring in the law of Serbia, Croatia, Bosnia and Herzegovina ${ }^{29}$ and Albania ${ }^{30}$. From the countries in the region, Macedonia has not adopted a special Law on Factoring. In the law of Macedonia, the general rules of the law of obligations apply to the factoring contract, while other issues related to factoring are regulated by the provisions of the Law on Financial Companies. Thus, factoring service is defined in the law of Macedonia, while the factoring contract is neither regulated nor defined.

In some countries, factoring is regulated through the Law on Obligations or codification of civil law. For example, in Estonia, a factoring contract is regulated by the Law on Obligations. On the other hand, factoring is not regulated in some countries. For example, in the law of Bulgaria, there is no special Law on Factoring, nor is the factoring contract regulated by the law of obligations (civil law) ${ }^{31}$ Also, factoring contract is not specifically regulated in the law of Cyprus, Poland, Slovakia, and Slovenia. In these countries, as well as in Montenegro, before the adoption of the Law on Financial Services, general rules of the Law on Obligations apply to the factoring contract. Even economically developed countries in which this contract originated, such as the United States and the United Kingdom, do not regulate this contract by special laws.

Hungary has a specific, and from the perspective of the activities on the drafting of the future civil code, a potentially interesting model, of a legally regulated factoring. Namely, in the law of Hungary, the factoring contract has been regulated by the provisions of the Civil Code since 2013, while other issues in relation to factoring services are regulated by other laws. ${ }^{32}$ The same model is

\footnotetext{
28 Notwithstanding the diversity of approaches to regulating factoring, factoring has undergone a dramatic increase in recent decades. For example, according to Factors Chain International, the total turnover from factoring operations in 2015 was EUR 1,557, out of which EUR 1,471 was made within the European Union, which is a stake of $62 \%$ of the total resultant factoring worldwide. See: Factors Chain International (accessed at: https://fci.nl/downloads/ annual-review-2016.pdf.).

29 Law on Factoring (Official Gazette of the Federation of Bosnia and Herzegovina, no. 14/16).

30 Law No. 9630 on Factoring. The definition of factoring contract has been taken from the Convention, also the law does not refer to the types of factoring transactions, but the types of factoring contracts.

31 See: EBRD, Factoring survey in EBRD countries of operation, 2016, p. 31.

32 Act V of 2013 on the civil code; Act CXII of 1996 on credit institutions and financial enterprises.
} 
also present in the law of Moldova, where the factoring contract is regulated by the provisions of the Civil Code. ${ }^{33}$ A specific model exists in the law of Lithuania. Namely, the Law on Financial Institutions of Lithuania stipulates that factoring is a financial service that can be performed by banks and financial institutions. However, factoring contract is not regulated and the general rules contained in the Civil Code apply to it. ${ }^{34}$ A similar model exists in the law of Romania, which defines factoring transaction and conditions for performing factoring operations, but factoring contract is not specifically regulated. In Italy, a special law (Law No. 52 from 1991) regulates the transfer of receivables, which is applied to the factoring contract. Factoring has been regulated in law of Germany' since 2008 through the Law on Banks. ${ }^{35}$ Factoring is also regulated by special law in the law of Greece. ${ }^{36}$

\section{CONCLUSION}

The frequent conclusions of certain innominate contracts over time point out the need to regulate them by law. This way, they receive a legal designation and become nominate and independent contracts, with a legal regime regulated by law. Legal regulation of the factoring contract gave rise to a new phase in the development of this economic activity in Montenegro. Despite not having a long history of existence in the law of Montenegro, factoring contract has gone through two phases of development so far. First, it was an innominate contract that was devised as a result of the specific need of business practice in the time of the financial crisis. After that, other forms of factoring which are common within comparative business practice began to develop gradually. At this point, the problem of trust of the business public has arisen, and the growth of interest for this activity is weak, despite the fact that there is room for improvement of factoring, primarily due to the expressed illiquidity of the economy. However, as we have already emphasized in this paper, it is necessary to make a distinction between the regulation of factoring as an economic activity and the factoring contract as a special sui generis contract of a business law. In this re-

33 Civil Code of Moldova no. 1107-XV.

34 Civil Code No. VIII-1864 of the Republic of Lithuania, Law No. IX-1068 on Financial Institutions. More details can be found at: EBRD, Factoring survey in EBRD countries of operation, p. 70.

35 The reason for the regulation was the fact that factoring companies in Germany wanted to enjoy certain tax reliefs that were reserved for the banking sector by December 24, 2008. In addition, it was decided that the factoring sector should be controlled by the German Financial Supervisory Authority.

36 Law on Factoring No. 1905/1990. 
gard, we emphasize that this difference was not fully defined by the legislator in Montenegro, as already presented in the analysis in this paper. Regardless of the time period of enactment of this Law and due to the importance of factoring and other forms of economic activity regulated by the Law on Financial Services, we believe that this approach of the legislator is not in the spirit of the tradition of Montenegrin contract law. On the contrary, proclaiming the principle of a unified regulation of obligation relations, Montenegro has regulated many economic-legal contracts through the Law on Obligations. The legislator had many similar solutions, which have been present in the law of Montenegro for many years and which have through different laws distinguished economic activities and contracts through which they are performed. For example, insurance, tourism and the like. It should be emphasized that in the light of the process of accession to the European Union, there is no imperative obligation of the said legislative solution to financial services, as applied in the law of Montenegro. Analysis of comparative models of the regulation of factoring operations, that is, the factoring contract in this paper, is the best confirmation for the stated position.

The above stated arguments are especially important for the activities in the process of the drafting of the future Civil Code. Namely, it would be logical and in line with the current legal tradition in Montenegro, that the factoring contract is regulated through this legal act. In this case, there would be a separation of status issues that regulate the provision of factoring and other financial services and contractual and legal provisions governing rights and obligations, as well as other issues of the matter under these obligation relations.

\section{LITERATURE:}

1. Matić, B.: Obrnuti faktoring u domaćem zakonodavstvu, 1(3) 2014, Pravo i privreda, p. $268-285$.

2. Bakker, M. et al.: Financing Small and Medium-size Enterprises with Factoring: Global Growth and Its Potential in Eastern Europe, The World Bank, 2004. (Accessed at http://documents.worldbank.org/curated/en/293341468770661333/pdf/ wps3342.pdf).

3. Brkić, A.: Normativno uređenje ugovora o faktoringu u svijetlu domaćih i međunarodnih izvora prava, 9(1) 2010, Anali Pravnog fakulteta Univerziteta u Zenici, p. 177-200.

4. Central Bank of Montenegro, Report on the stability of the financial system for 2017.

5. EBRD, Factoring survey in EBRD countries of operation, 2016, p. 31. 
6. Marković, V.: Ugovor o faktoringu u pravu Republike Srbije, 5(2) 2014, Pravni zapisi, p. 493-504.

-DOI: https://doi.org/10.5937/pravzap0-6931

7. Mikerević, D.: Šanse i zamke faktoringa u saniranju nelikvidnosti preduzeća i privrede, 9(18) 2013, Acta Economica, 191-217.

8. Milenkovic-Kerković, T.; Dencic-Mihajlov, K.: Factoring in the Changing Environment: Legal and Financial Aspects, 44 (1) 2012, Procedia - Social and Behavioral Sciences, p. $428-435$.

-DOI: https://doi.org/10.1016/j.sbspro.2012.05.047

9. Milenković-Kerković, T.; Atanasković, Ž.: Ugovor o faktoringu u Srbiji - Zbog čega je potrebno regulisati faktoring?, 7(9)2013, Pravo i privreda - časopis za privrednopravnu teoriju i praksu.

10. Milosavljević, M.: Privredno ugovorno pravo, Novi Sad, 2009, p. 121.

11. Radomir, Đ. Međunarodno privredno pravo, Beograd, 2004.

12. Ristić, D.; Rička, Ž.: Mogućnost korišćenja faktoringa na tržištu Bosne i Hercegovine i regije, 17(35) 2015, Tranzicija, p. 57-75.

13. Spasić, I. et al.: Factoring - instrument of financing in business practice - some important legal aspects, 25(1) 2012 Ekonomska istraživanja, p. 191-211.

-DOI: https://doi.org/10.1080/1331677X.2012.11517502

14. Vasiljević, M.: Trgovinsko pravo, Beograd, 2011, p. 370.

15. Vukadinović, R.: Značaj i uloga faktoringa kao instrumenta finansiranja izvoza iskustva novih članica Evropske unije, 165(1) 2005, Economic Annals, p. 81-104. -DOI: https://doi.org/10.1080/1331677X.2012.11517502

\section{LEGISLATION}

1. Civil Code No. VIII-1864 of the Republic of Lithuania.

2. Civil Code of Moldova no. 1107-XV.

3. Factoring Law of Bosnia and Hercegovina (Official Gazette of the Federation of Bosnia and Herzegovina, no. 14/16).

4. Factoring Law of Croatia (NN, 94/14, 85/15, 41/16).

5. Factoring Law of Greece No. 1905/1990.

6. Factoring Law of Serbia (Official Gazette of the Republic of Serbia no. 62/2013, 30/2018).

7. Law on Financial Leasing, Factoring, Purchase of Receivables, Micro-Lending and Credit-Guarantee Operations (Official Gazzette of Montenego, no. 073/17).

8. UNIDROIT Convention on international factoring, Art 1. (accessed at: https:// www.unidroit.org/instruments/factoring). 